\title{
Analysis of the Worn-Out Tissues Characteristics and Providing of Intervention Pattern, Case Study: Eslamshahr City, Tehran
}

\author{
Abbas Samiei*, Alireza Sayafzadeh \\ Geography and Planning College, Payame Noor University, Shahr-e-Ray, Tehran, Iran \\ Email: "Samiei770@Gmail.com, Samiei1395@,Gmail.com
}

How to cite this paper: Samiei, A., \& Sayafzadeh, A. (2016). Analysis of the Worn-Out Tissues Characteristics and Providing of Intervention Pattern, Case Study: Eslamshahr City, Tehran. Current Urban Studies, 4, $267-$ 279.

http://dx.doi.org/10.4236/cus.2016.43018

Received: June 22, 2016

Accepted: August 14, 2016

Published: August 17, 2016

Copyright (c) 2016 by authors and Scientific Research Publishing Inc. This work is licensed under the Creative Commons Attribution International License (CC BY 4.0).

http://creativecommons.org/licenses/by/4.0/

\section{Abstract}

This paper aims to prioritize intervention in urban deteriorated fabrics of Eslamshahr city. Worn-out textures in Eslamshahr (south west neighbor of Tehran), despite having potential facilities, unfortunately, in areas such as network infrastructure, water, electricity, telephone, and gas networks are becoming physical problems of the city against unforeseen events such as an earthquake. So that improvement, renovation and restoration of these textures could be very effective in making the Eslamshahr development sustainable. The studied deteriorated fabric covers an area of 104 hectares and has a population of about 42,664 people. Problems and challenges such as the domain of low-income people living, non-proportional distribution of services, marginalization and extensive urban deteriorated are among the most evident challenges. In this study, using the analytic hierarchy process (AHP), the weighting and ranking of triple structures and variables related to each structure of the worn-out texture in Eslamshahr region took place. Weighting of criteria has been carried out based on research and comment of professionals and experts. Intervention indicators in the studied fabric are recognized and prioritized based on physical, social and economic factors. Considered indicators include type of Land Use, Passage network, Building occupies, Building Density, Number of floors, Building Life, Number of blocks, Constructions materials and skeleton, Separation of parts and Building quality. After evaluation using analytical hierarchy process and according to opinions of experts, rank each of the parameters was obtained and then with using ArcGIS software overlay map have been designed and evaluated. Result of this study revealed which a pattern can be presented for intervention of worn-out texture in Eslamshahr.

\section{Keywords}

Worn-Out Texture, Prioritization of Intervention, Modernize, Improvement, AHP Method, Eslamshahr 


\section{Introduction}

Worn-out texture is one of the important issues in public policy making, which is brought many consistent pursuits and interests during the past two decades in theoretical and practical fields (Ford, 1999; Roberts and Huag, 2002; Habibi et al., 2007; Hajipour, 2007; Jahanian and Pajoohan, 2011; Sedaghat Rostami et al., 2011; Sharifzadegan et al., 2011). More than 40 thousand hectares of these textures have been identified in Iran (Shamaaei \& Poor Ahmad, 2005; Poorahmad et al., 2010; Nikookar and Ahmadi, 2015). Renovation of the worn-out textures within the cities is counting a type of urban, which known as "Urban growth from within", provided functional strategies based on the potentials of under survival arias. Worn-out texture within itself that considering and planning for renovation and improvement of the texture meanwhile solving the existing problems could provide the needs of the city development, at least in part (Habibi et al., 2007; Hajipour, 2007; Jahanian and Pajoohan, 2011; Sedaghat Rostami et al., 2011; Sharifzadegan et al., 2011).

Although damage causes inefficient and reduces efficiency and eventually leads to the physical and functional deterioration of urban and this is a negative point, at the same time, is creating opportunities for intervention that can be used to develop strategies to reduce risks and to repair textures when necessary (Ford, 1999; Roberts and Huag, 2002; Nikookar and Ahmadi, 2015). The quality of a space in a city is achieved from components, identifying by appropriate functions and effects of each strategies on the spaces. It provides approaches to improve the quality of city spaces, which is more important than the worn-out textures (Shamaaei and Poor Ahmad, 2005). Notably, the most essential aim and basic approach are interventional actions to improve texture of downtown and restore the complex for urban life cycle (Jahanian and Pajoohan, 2011; Nikookar and Ahmadi, 2015). The old textures cannot provide good services to their population, so that privileged and middle class social communities are moving from there to the renewal part of city and the area is becoming a place for various cultural groups and in such conditions social aberrant increases in the old and worn-out textures (Hataminejad and Mollaeri, 2011).

This study aimed to analyze of the worn-out Textures characteristics and providing of intervention pattern in Eslamshahr from Tehran/Iran. Released textures in Eslamshahr, despite having potential facilities, unfortunately, in areas such as network infrastructure, water, electricity, telephone, and gas networks are becoming physical problems of the city against unforeseen events such as an earthquake. So that improvement, renovation and restoration of these textures could be very effective in making the Eslamshahr development sustainable.

\section{Studied Area, Material and Method}

Eslamshahr city, south west neighbor of Tehran in the years 40 s, included a set of villages and slums (Figure 1) that had grown considerably during Revolution years (Rafieian et al., 2014). The rate of population growth since the beginning of the city formation, and also high rate of immigration to it and consequently high ethnic diversity 

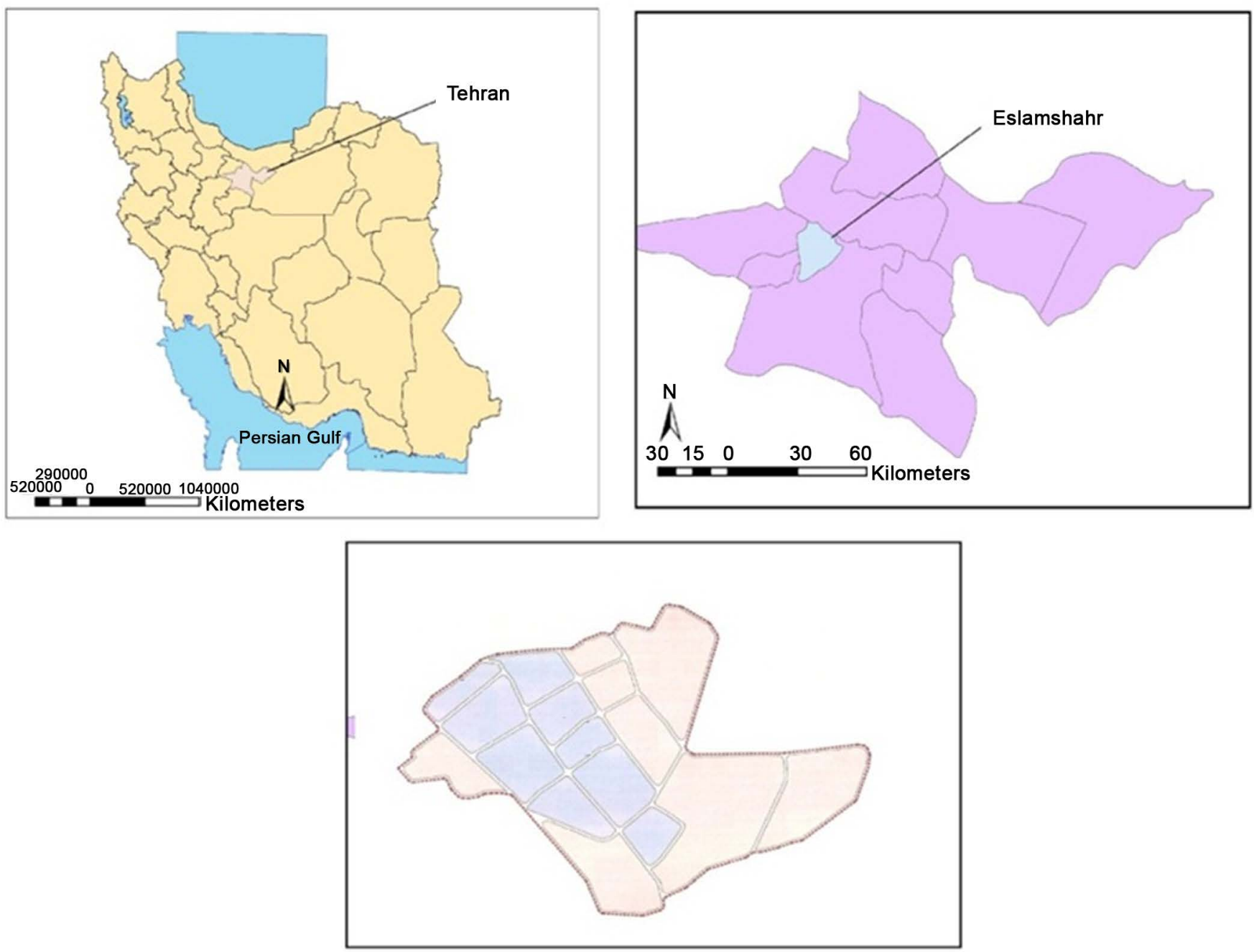

Figure 1. Studied area.

have been effective on occurring urban problems and challenges.

Problems and challenges such as the domain of low-income people living, non-proportional distribution of services, marginalization and extensive urban deteriorated are among the most evident challenges (Rafieian et al., 2014). The existence of such urban challenges and problems, considering city development strategic plan, are among the causes that make this city selected as the case study so that after studying the conditions governing upon city and determining its situation in all determined criterion and sub-criterion, the possibility of application of urban development strategic planning in this city will be studied.

The studied deteriorated fabric covers an area of 104 hectares and has a population of about 42,664 people. According to the data, this fabric is in critical state with more than $85 \%$ damaged buildings and over $80 \%$ deadlock alleys, despite being very narrow, that have caused access problems due to density congestion and expansion of fine grains in the area. Figure 1 displays the situation of deteriorated urban fabric and the studied area. 
This study has a goal to be applicable and the descriptive-analytic method is used for data collection. To meet and achieve the ultimate goal of the research, production and creation of data related to the physical, social and economic factors impacting modernization and development of worn-out textures have taken place. Then, using the analytic hierarchy process (AHP), the weighting and ranking of triple structures and variables related to each structure of the worn-out texture in Eslamshahr region took place.

The analytic hierarchy process (AHP) is a structured technique for organizing and analyzing complex decisions (Ghodsipoor, 2002, Zebardast and Esfandiar, 2006; Ananda and Herath, 2003). The analytical Hierarchy Process has particular application when the issue is capable of being analyzed to a hierarchy of decision making criteria. This method is accomplished in 4 following consecutive steps:

- First step: Defining hierarchies.

- Second step: Weighting criteria.

- Third step: Weighting alternatives.

- Fourth step: Combining results.

AHP begins by defining the basic issue and requires a hierarchy for decision-making which includes decision criteria. These criteria are arranged in descending order from the goal to criteria and sub-criteria. Hierarchy should include all necessary aspects for the decision-making process while not being too detailed to lose sensitivity to changes (see Ghodsipoor, 2002, Zebardast and Esfandiar, 2006). The decision maker does a pairwise comparison of decisions and criteria in the form of a matrix. Once performed the paired comparison between the criteria and alternatives, mathematical techniques will be used to determine the weight of each of the comparison matrix in the hierarchy. The final weights obtained are the measurement of the ratio of priority criteria, subcriteria and alternatives (see Ghodsipoor, 2002, Zebardast and Esfandiar, 2006). In this study, Weighting of criteria has been carried out based on research and comment of professionals and experts.

\section{Main Criteria of Worn Textures and Planning Required}

The main criteria for the establishment of the process of weariness of urban texture are:

1) Micro-residential blocks, indicating tightness and intensity of the blocks, more than $50 \%$ of blocks possess less than 120 square meters.

2) Fabric instability, inappropriate structural system and lack of strength in buildings.

3) Inscrutability, indicating lack of access to and appropriate network of passages-Alleys less than $6 \mathrm{~m}$ in width (Monjezi and Mohammadi, 2015).

Hyogo's framework has 3 steering goals and is the most integrated and comprehensive global framework in disaster risk reduction and management. The steering goals of Hyogo's framework are:

A) Integration of the most influential considerations of disaster risk reduction into the policies and sustainable development programs. 
B) Development and strengthening of institutions, mechanisms and capacities in all levels of local communities with the aim of helping empowering confronting risks.

C) Introducing reduction of risk taking approaches in the design and implementation of preparedness, respond and reconstruction of hazard destructed areas (Farhadi, 2013).

Main schools in the scope of urban improvement and renovation are listed in order in the Table 1.

The old areas of the city those at the time of formation were responsive to the hierarchy needs of their residents following with changes in technology and in the biological, cognitive, social and economic needs have no strong performance, currently. These areas were the center of power and wealth in cities once, but in the current situation (in most cities) in terms of access to infrastructure and municipal services are weak and in terms of physical are poor (Maleki, 2010; Nikookar and Ahmadi, 2015).

Damaging is a reality that most of the historical cities of Iran have been affected. Certainly, in these cities, it interrupts urban texture growing and bring it to the edge, therefor besides destruction of inner and old textures of the city, imposes the enormous cost of creating new texture (Pourahmad et al., 2005). On the one hand the high extent of urban worn-out textures and their vulnerability when natural disasters coming on the other hand make their renovation to be one of main issues in the field of urban development (Nikookar and Ahmadi, 2015). In these textures most spaces have been damaged and their component quality is deficient, which over time can lead to the loss of life of a texture and its surrounded environment (Nikookar and Ahmadi, 2015). On the other hand a safe and practical way for the urban planners to supply appropriate housing is using the potential of urban worn-out textures, which can be achieved with spending less cost and time through organizing these textures (Zenoozi, 2000).

Table 1. Theories of improvement of worn-out textures (Shahidi, 2009).

\begin{tabular}{|c|c|}
\hline $\begin{array}{c}\text { Cultural } \\
\text { orientation }\end{array}$ & $\begin{array}{l}\text { Priority of spiritual needs over material ones: improvement } \\
\text { and renovation through revival of the past cultural values. }\end{array}$ \\
\hline $\begin{array}{l}\text { Progressive } \\
\text { orientation }\end{array}$ & $\begin{array}{l}\text { During renovation and reconstruction of the old cities, } \\
\text { nothing is preserved except the roads }\end{array}$ \\
\hline Ecological school & $\begin{array}{c}\text { Recession of old texture because of social and economic groups } \\
\text { and segregations due to social injustice }\end{array}$ \\
\hline $\begin{array}{l}\text { Functional } \\
\text { orientation }\end{array}$ & $\begin{array}{l}\text { Improvement and renovation for the aim of economic } \\
\text { and functional development of the city }\end{array}$ \\
\hline $\begin{array}{l}\text { Structural } \\
\text { orientation }\end{array}$ & $\begin{array}{l}\text { Collective like and systemic attitude towards city: improvement of fabric } \\
\text { and spatial structures in collections and no single buildings. }\end{array}$ \\
\hline Modernism & $\begin{array}{l}\text { Extreme inclination for preservation of old monuments that even } \\
\text { required the renovation and improvement of dead and non-historic buildings. }\end{array}$ \\
\hline Post modernism & the sense of locality, revival of what that possesses local and special value. \\
\hline Humanism & $\begin{array}{l}\text { Considering people and their partnership in improvement } \\
\text { and renovation of urban space and people-oriented intervention. }\end{array}$ \\
\hline
\end{tabular}




\section{Most Important Issues and Problems of Worn Textures}

In general, the most important issues and problems of worn textures can be classified as follows (Pour Saraskanroud et al., 2011).

\subsection{Socio-Economic Problems}

Gradual exit of old residents from the district, migration of noble social strata from the old quarters and their replacement with incongruent migrants who are in lack of any ties to these regions, the growth and expansion of various types of social violations, allocation of old textures to specific and low grade activities which absorb violators and addicts, negative growth rate of household and population, demolishing the past economic structure of the old texture which was based on bazaar, the high cost of renovation of constructional units (this factor makes private sector investors to distance themselves from investments in these areas), the low income level and inability in private investment and incapability to absorb peoples contributions (Jamal, 2007).

\subsection{Environmental Problems}

Another factor which has impacts on the worn out state of a historical texture is environmental pollution. Due to the concentration of business and work place spaces and consequently the establishment of various types of terminals and storerooms, over traffic of cars inside the texture, air and noise pollution takes place. These pollutions reduce the qualitative value of life and welfare of residents. It also stops the growth and development of urban texture, increases migration to that urban area and finally it hinders the innovation of worn out texture. Noise pollution also has impacts on the spirit and body health of the residents and reduces the qualitative and quantitative values of life in that texture (Habibi et al., 2007).

\subsection{The Skeleton and Accessibility}

Problems: The low quality of the texture and using unfavorable products, full adaptability of the old texture with worn out textures and the existence of various limits of historical monuments, high population density along with low construction density, intensive shortage of urban public services like per capita green space or urban equipment's, location improper distribution of urban services, division of lands of the region into small pieces and fine-grained condition of textures, the lack of infrastructures in harmony with the population at the region level such as parking, intensive skeleton vulnerability at the time of natural dangers such as earthquake, using low durable products such as bricks, dried bricks and wood (Arab Ahmadi, 2007).

\section{Prioritize Intervention}

Deteriorated fabric is the whole or part of urban space whose living systems are faced with inefficiency and disorder both in terms of function and construction. In other words, urban deteriorated fabrics are urban zones that are eroded due to urban and 
spatial decentralization and faced with economic, social, physical and environmental problems (Toopchi Sani, 2010; Alipoor, 2012; Shahkarami, 2016).

These fabrics that have shaped and evolved in a long period of time have to cope with current contemporary technological developments. Although these areas contained logical and hierarchical functions in t the past time, they are experiencing structural and functional deficiencies right now that cannot meet the needs of residents (Habibi, et al., 2007; Shahkarami, 2016). Moreover, there is no possibility of self-renewal by residents and owners in the area due to poverty. Therefore, the need to identify and reorganize these old fabrics is highly essential.

This paper aims to prioritize intervention in urban deteriorated fabrics of Eslamshahr city. In this regard, socio-economic and environmental effects as well as physical parameters in prioritization is queried.

However, as a basic premise we must accept that most of the information needed to calculate the indices of socio-economic requirements are either not produced or limitedly produced in Iran. The mentioned studies are carried out under the standards of city territories that may not match the limitations of the current study. Therefore, these limitations can downgrade the depth and width of socio-economic analysis.

\section{Research Background}

A literature review suggests that the identification of deteriorated fabric has changed from focusing on physical approaches to social, economic, environmental and cultural considerations. However in most researches such as Hajipour (2007); Jahanian and Pajoohan (2011); Sedaghat Rostami et al. (2011), this issue is presented quantitatively and not qualitatively (see Shahkarami, 2016).

Meanwhile, few attempts have been conducted recently by researchers of this field using quantitative measures and modeling. Sharifzadegan et al. (2011) have used the SPSS Statistical software, factor analysis, and principal component analysis as well as varimax rotation method in order to define intervention priority in deteriorated blocks of district 15 of Tehran. Not only have they considered physical indicators, but also other variables such as the average household size, average sex ratio as social indicators as well as the average internal rate of return as economic indicators were used. Bemanian and Rezayi Rad (2012) have used factor analysis and Delphi method using GIS to determined physical deteriorated fabric of Khak Sefid neighborhood in Tehran and define intervention priorities. In addition to defining physical indicators such as fine grain, instability and impermeability, they have used other indicators in the model such as the age, quality of construction and building materials. The studies also stated that investigating these factors will lead to a better understanding of deteriorated fabric. Alipoor and colleagues also involved environmental quality standards other than physical measures approved by the Supreme Council of Architecture and Urbanism, (as functional, aesthetic, and ecological sub-criteria) in order to identify priorities for intervention in the deteriorated fabric of the old city of Bandar Lengeh. They used AHP method and GIS software inorder to give weight to indicators and sub-criteria and 
present a priority intervention map. As noted above, the techniques that are reviewed in researches of priority intervention zones have tried to represent new criteria other than physical characteristics.

\section{Determining Intervention Indicator}

As noted in this study, intervention indicator in the studied fabric are recognized and prioritized based on physical, social and economic factors (see Toopchi Sani, 2010; Alipoor, 2012; Shahkarami, 2016). Therefore, the corresponding layer of determining and prioritizing of intervention zones for each of the physical, socio-economic and environmental factors were provided by use of indicators and variables. Finally and according to combination methods, zones in need of intervention in deteriorated fabrics were defined by overlaying of the three mentioned layers.

Considered indicator include type of Land Use, Passage network, Building occupies, Building Density, Number of floors, Building Life, Number of blocks, Constructions materials and skeleton, Separation of parts and Building quality (Table 2, Figure 2 and Figure 3). Any mentioned parameters divided to subclass and are ranked to three levels

Table 2. Prioritization criteria based on the intervention.

\begin{tabular}{|c|c|c|c|c|}
\hline Criteria & High priority & Middle priority & Low priority & $\begin{array}{l}\text { Weight } \\
\text { (AHP) }\end{array}$ \\
\hline Land Use & $\begin{array}{l}\text { Vacant land } \\
\text { Abandoned } \\
\text { Ruin } \\
\text { Parking and storage } \\
\text { Residential } \\
\text { Residential Mixed }\end{array}$ & $\begin{array}{l}\text { Training } \\
\text { Industry and } \\
\text { non-obtrusive workshop } \\
\text { Health } \\
\text { Commercial } \\
\text { Reception }\end{array}$ & $\begin{array}{l}\text { Religious } \\
\text { Under Construction } \\
\text { Green space } \\
\text { Facilities and equipment } \\
\text { Official } \\
\text { Heritage }\end{array}$ & 0.211 \\
\hline Passage network & Less than 7 meters & 8 to $29 \mathrm{~m}$ & More than 29 meters & 0.167 \\
\hline Building occupies & 50 to 60 percent & 30 to 50 percent & 60 to 100 percent & 0.061 \\
\hline Building Density & $\begin{array}{l}\text { Less than } \\
100 \text { percent }\end{array}$ & 100 to 120 percent & 120 to 300 percent & 0.166 \\
\hline Number of floors & Less than 2 floors & 2 to 4 floors & 4 to 6 floors. & 0.03 \\
\hline Building Life & Over 30 years & 10 to 30 years & Less than 10 years & 0.041 \\
\hline Number of blocks & $\begin{array}{l}\text { Less than } 40 \text { part on } \\
\text { the block }\end{array}$ & $\begin{array}{l}40 \text { to } 80 \text { part on the } \\
\text { block }\end{array}$ & over 80 part on the block & 0.21 \\
\hline $\begin{array}{l}\text { Constructions } \\
\text { materials } \\
\text { and skeleton }\end{array}$ & $\begin{array}{l}\text { Without Reliable } \\
\text { structural } \\
\text { component }\end{array}$ & - & $\begin{array}{l}\text { With Reliable structural } \\
\text { component }\end{array}$ & 0.071 \\
\hline Separation of parts & $\begin{array}{l}\text { Less than } \\
100 \text { meters }\end{array}$ & 100 to 200 meter & More than 200 meters & 0.158 \\
\hline Building quality & Destructive & $\begin{array}{l}\text { No information } \\
\text { Maintainable }\end{array}$ & $\begin{array}{l}\text { Restoration } \\
\text { Renovation }\end{array}$ & 0.0171 \\
\hline
\end{tabular}



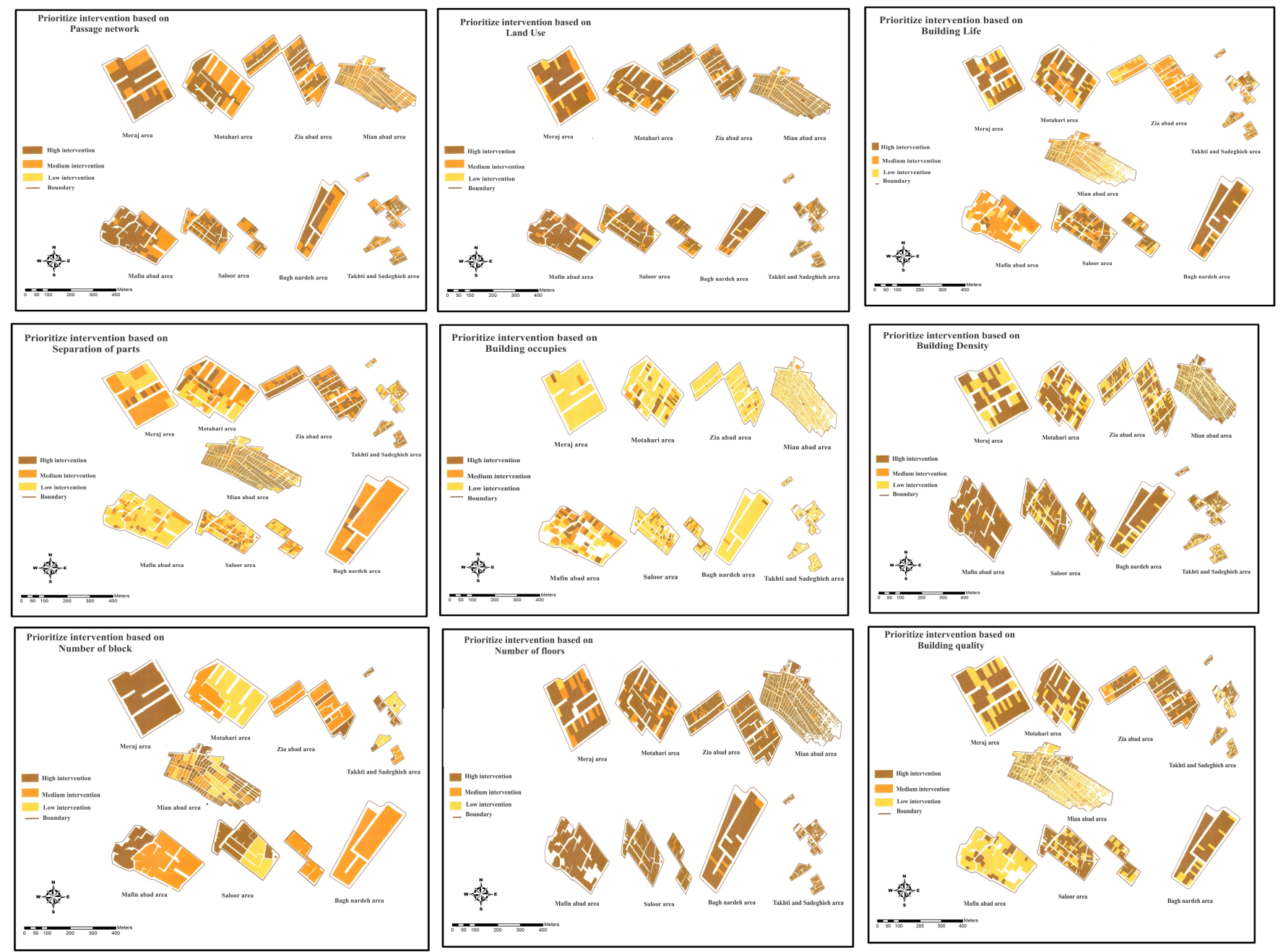

Figure 2. Prioritization criteria based on the intervention.

high, middle and low priority of intervention. After evaluation using Analytical Hierarchy Process and According to opinions of experts, Rank each of the parameters was obtained and then with using ArcGIS software overlay map have be designed and evaluated.

\subsection{Land Use Indicator}

As show in Table 1, Land Use indicator divided to various subclasses such as vacant land, Abandoned, Ruin, Parking and storage, Residential, Residential Mixed which have High priority. Land Use Indicator with Medium priority is Training, Industry and non-obtrusive workshop, Health, Commercial and Reception. Low priority subclasses of Land Use indicator include Religious, Under Construction, Green space, Facilities and equipment, Official, Heritage (Table 1 and Figure 2).

\subsection{Passage Network Indicator}

Passage network have close relationship with activity of area and have mutual effects. 


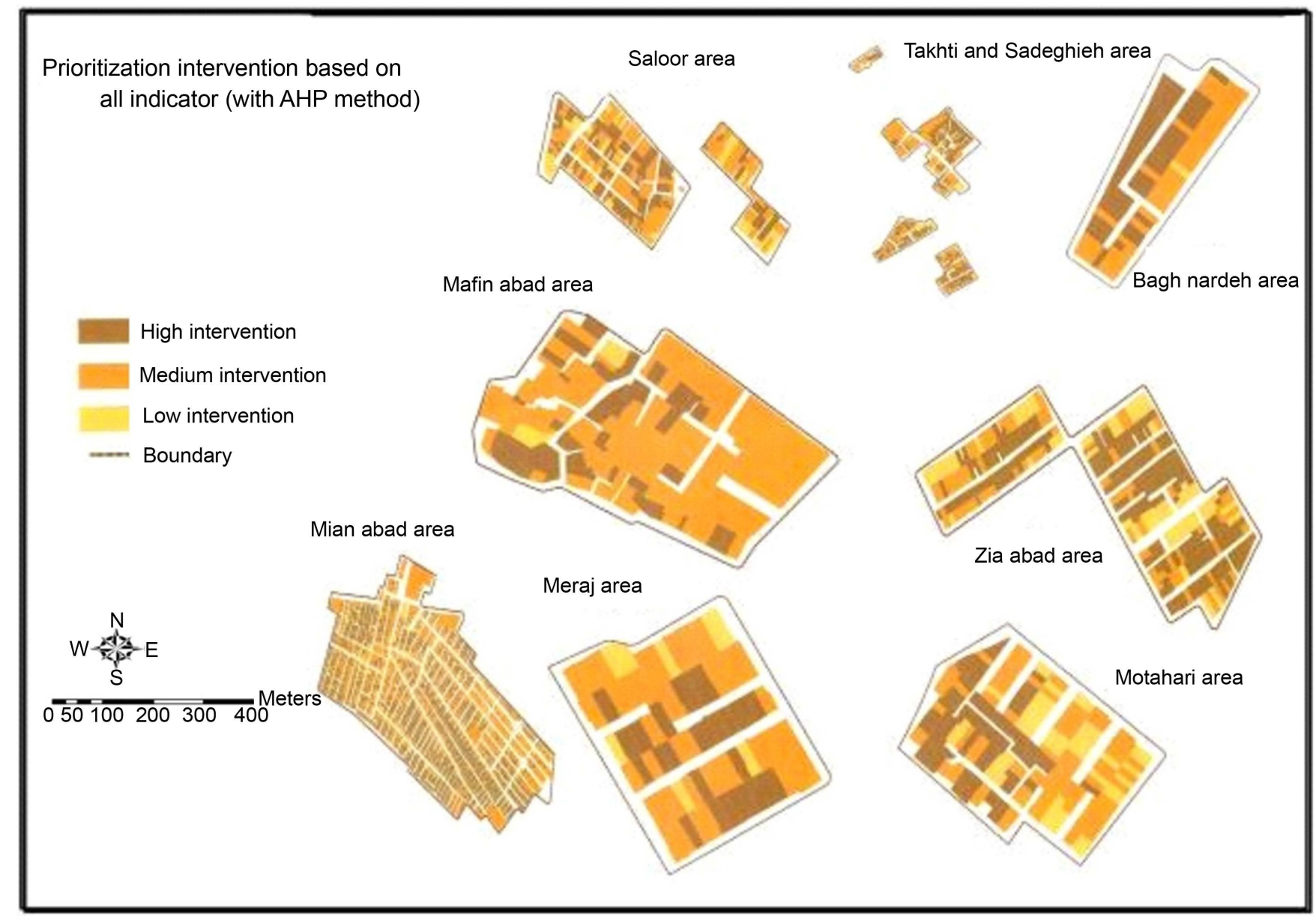

Figure 3. Prioritize intervention in the quarters.

Improve the structure came development for the areas and make Economic and social development and diversification of activities. In other words, communication network due to interplay is important. For example $30 \%$ of urban land of every city included Passage network. Roads and communication networks of a city can be considered as most important characteristics which are reflects physical "need to access". On the other hand Gutenberg believed progress and development of society and city have been recognized in to "need to access" concept.

\subsection{Building Occupies Indicator}

The building occupies is entire land which covered by residential buildings. Entry platforms, stairs, terraces, not to be calculated as building occupies. For this indicator (Building occupies), parts of texture that have Building occupies low than 50 to 60 percent considered Low intervention priority. Medium and high priority included land with 30 to 50 and also 60 to 100 Building occupies, respectively (Table 1 and Figure 2).

\subsection{Building Density Indicator}

Building Density is Concentration (amount) of buildings in a given geographic area. 
Building Density is one of the most important issues in urban planning and urban development, which in recent years to be considered as profitable criteria for the city and caused of many parameters ignoring. Building Density indicator, low than 100 Building Density is considered as Low intervention priority and 100 to 200 and also 200 to 300 have been interpreted as medium and high intervention priority (Table 1 and Figure 2).

\subsection{Number of Floors Indicator}

Number of floors indicator are considered as one of the factor which use for intervention in the worn out texture. In the worn out texture, the lower floors of building are older ration to the Upper floors and subsequently their intervention is less expensive and easier. Therefore lower floors have higher intervention priority (Table 1 and Figure 2).

\subsection{Building Life Indicator}

The older buildings have more priority for intervention. The building with more 40 years old is considered as Low intervention priority, 30 to 40 are medium and lower 10 years is high intervention priority (Table 1 and Figure 2).

\subsection{Number of Blocks Indicator}

As show in Table 1, Blocks with more than 40 parts are considered high intervention priority and 40 to 80 and also more than 80 have medium and low priority for intervention, respectively (Table 1 and Figure 2).

\subsection{Constructions Materials and Skeleton Indicator}

As noted in the Table 2, this indicator divided two item based on priority. Buildings without reliable structural component have higher priority than building with Reliable structural component (Table 1 and Figure 2).

\subsection{Separation of Parts Indicator}

Types of Less than 100 meters are high intervention priority, 100 to 200 is medium and more than 200 considered as building with low priority for intervention (Table 1 and Figure 2).

\subsection{Building Quality Indicator}

Quality of Construction in the city texture largely depends on the technology and materials. In this study, historical buildings with term of Building quality indicator considered as high intervention priority (Table 1 and Figure 2).

\section{Conclusion}

In this study, using the analytic hierarchy process (AHP), the weighting and ranking of triple structures and variables related to each structure of the worn-out texture in Es- 
lamshahr region took place. Weighting of criteria has been carried out based on research and comment of professionals and experts. Intervention indicators in the studied fabric are recognized and prioritized based on physical, social and economic factors. Considered indicator includes type of Land Use, Passage network, Building occupies, Building Density, Number of floors, Building Life, Number of blocks, Constructions materials and skeleton, Separation of parts and Building quality. Any mentioned parameters divided to subclass and are ranked to three levels high, middle and low priority of intervention. After evaluation using Analytical Hierarchy Process and According to opinions of experts, Rank each of the parameters was obtained and then with using ArcGIS software overlay map have be designed and evaluated. Finally, some result which revealed in this study mentioned at the bellow.

Land Use indicators are divided to various subclasses such as vacant land, Abandoned, Ruin, Parking and storage, Residential, Residential Mixed which have high priority. For building occupies indicators, parts of texture that have building occupies lower than 50 to 60 percent considered low intervention priority. Building density indicator, lower than 100 building density is considered as low intervention priority and 100 to 200 and also 200 to 300 have been interpreted as medium and high intervention priority. The building with more 40 years old is considered as low intervention priority, 30 to 40 are medium and lower 10 years are high intervention priorities. Blocks with more than 40 parts are considered high intervention priority. Types of less than 100 meters are high intervention priority, 100 to 200 are medium and more than 200 are considered as buildings with low priority for intervention.

\section{References}

Alipoor, R. et al. (2012). Environmental Quality Indicators in Identifying Priorities for Intervention in Deteriorated Fabrics in City of Bandar Lengeh. Journal of Bagh-e Nazar, 9, 13-22.

Ananda, J., \& Herath, G. (2003). The Use of Analytic Hierarchy Process into Regional Forest Planning. Journal of Forest Policy and Economics, 15, 13-26.

http://dx.doi.org/10.1016/S1389-9341(02)00043-6

Arab Ahmadi, M. (2007). Introduction to Urban Worn Textures and Method of Their Formation. Municipalities Monthly Journals, 81 .

Bemanian, M. R., \& Reazayi Rad, H. (2012). Assessing Factor Analyst and Delphi Models by Use of GIS in Recognizing Deterioration in Urban Fabric. Journal of Hoviat Shahr, 6, 5-16.

Farhadi, M. (2013). Consultant to the Red Crescent Population Manager, Chief Consultant of U.N in Risk taking Management. Quarterly Journal of Rescue and Relief, 3, 108-110.

Ford, R. D. (1999). Strategic Management. In A. Parsaeian, \& S. M. Arabi (Translated), Cultural Research Bureau (17th ed.). Tehran.

Ghodsipoor, H. (2002). Analytical Hierarchy Process (AHP). Tehran: Amirkabir Publication. (Original Work Published in 2000)

Habibi, K., Pourahmad, A., \& Meshkini, A. (2007). Regeneration and Rehabilitation of Old Urban Fabrics. Sanandaj: Publication of Kordestan University and Civil and Urban Development Organization (Original Work).

Hajipour, K. (2007). Introduction to Evolution and Development of Urban Restoration Approaches (the Period after the First World War to the Beginning of the Third Millennium). Journal of Andishe Iranshahr, 2, 16-25. 
Hataminejad, H., \& Faraji Mollaei, A. (2011). Feasibility of Execution of Urban Development Strategy Plans in Iran. Urban and Regional Studies and Researches.

Jahanian, M., \& Pajoohan, M. (2011). Analysis and Classification of Urban Deteriorated Areas in the Metropolis of Tehran and Intervention Strategies in It. Journal of Human Geography, 3, 93-106.

Jamal, M. J. (2007). Planning and Design for Worn and Inefficient Urban Textures with and Emphasize on Peoples Participation. Municipalities Monthly Review, 81.

Maleki, J. (2010). Introduction to City Development Strategy: Advantages and Problems. Second Conference of Planning and Urban Management Ferdowsi University, Mashhad.

Monjezi, F., \& Mohammadi, H. B. (2015). Reconstruction of Urban Worn-Out Textures and Reduction in Risk Taking (Case Study: Shushtar City). American Journal of Civil Engineering, 3, 24-29.

Nikookar, M., \& Ahmadi, N. (2015). Analysis of the Performance Characteristics of Borujerd Worn-Out Textures Using S.W.O.T. Science Journal (CSJ), 36.

Poorahmad, A., Habibi, K., \& Keshavarz, M. (2010). The Evolution of the Concept of Urban Renewal as a New Approach in Urban Deteriorated Fabric. Journal of Shahr-e Irani Islami, No. 1, 73-92.

Pour Saraskanroud, M., Pourahmad, A., \& Abedini, A. (2011). Proper Strategies for the Improvement and Renovation of the Worn Out Textures of Sirous District in Tehran Using SWOT Technique. Geography and Environmental Planning, 40.

Pourahmad, A., \& Shamei, A. (2005). Urban Improvement and Renovation from the Viewpoint of Geography. Tehran: University of Tehran Press.

Rafieian, M., Mohammadi, M., \& Mirzakhalili, N. (2014). Feasibility of City Strategic Planning with Approach of CDS; Case Study: Eslamshahr. Journal of Civil Engineering and Urbanism, 4, 96-104.

Roberts, P., \& Sykes, H. (2000). Urban Regeneration. London: SAGE Publication.

Rostami, S. et al. (2011). Develop Indicators to Identify Dysfunctional Fabrics. Journal of Spatial Planning, 1, 103-120.

Shahidi, A. (2009). Social Consequences of Development and Modernization of Space for Residents and Local Businesses Tabarestan Central City of Mashhad. MS Thesis, Earth Sciences Faculty, Tehran: Shahid Beheshti University.

Shahkarami, N. (2016). Prioritize of Intervention Zones in Central Deteriorated Fabrics of Arak City According to Functional, Socio-Economic and Environmental Indicators. Bagh-e Nazar, 13.

Shamaaei, A., \& Ahmad, P. (2005). An Analysis of Urban Policies and Programs of Improvements and Renovations in National Development Programs. Quarterly of Geographical Research, No. 48, 112 .

Sharifzadegan, M. H. et al. (2011). Determine Priority Modernization Areas with Urban Decline by Using the Factor Analysis and Model Boolean Logic, Case Study: Region 15 of Tehran. Journal of Urban Management, No. 27, 217-228.

Toopchi Sani, A. (2010). Urban Regeneration, New Approach to Intervention in Urban Deteriorated Fabrics. MSc Thesis of Urban Engineering, Esfahan: Esfahan University.

Zebardast \& Esfandiar (2006). Application of AHP in Planning. Fine Arts Quarterly, No. 1, 4-56.

Zenoozi, F. (2000). Basic Problems of Improvement and Renovation of Historical and Old Centers of Cities, (1975-2000). Journal of Architecture and Urbanism, Nos. 58, 59. 
Submit or recommend next manuscript to SCIRP and we will provide best service for you:

Accepting pre-submission inquiries through Email, Facebook, LinkedIn, Twitter, etc. A wide selection of journals (inclusive of 9 subjects, more than 200 journals)

Providing 24-hour high-quality service

User-friendly online submission system

Fair and swift peer-review system

Efficient typesetting and proofreading procedure

Display of the result of downloads and visits, as well as the number of cited articles

Maximum dissemination of your research work

Submit your manuscript at: http://papersubmission.scirp.org/ 